2 Repapi E, Sayers I, Wain LV, et al. Genome-wide association study identifies five loci associated with lung function. Nat Genet 2009; 42: 36-44.

3 Hancock DB, Eijgelsheim M, Wilk JB, et al. Meta-analyses of genome-wide association studies identify multiple loci associated with pulmonary function. Nat Genet 2009; 42: 45-52.

4 Young RP, Hopkins R, Black PN, et al. Functional variants of antioxidant genes in smokers with COPD and in those with normal lung function. Thorax 2006; 61: 394-399.

5 Molfino NA. Genetics of COPD. Chest 2004; 125: 1929-1940.

6 Young RP, Hopkins RJ, Whittington CF, et al. Individual and cumulative effects of GWAS susceptibility loci in lung cancer: associations after sub-phenotyping for COPD. PLoS One 2011; 6: e16476.

7 Løkke A, Lange P, Scharling H, et al. Developing COPD: a 25 year follow up study of the general population. Thorax 2006; 61: 935-939.

8 Young RP, Hopkins RJ, Eaton TE. Forced expiratory volume in one second: not just a lung function test but a marker of premature death from all causes. Eur Respir J 2007; 30: 616-622.

9 Mahajan N, Bahl A, Dhawan V. C-reactive protein (CRP) upregulates expression of receptor for advanced glycation end products (RAGE) and its inflammatory ligand EN-RAGE in THP-1 cells: inhibitory effects of atorvastatin. Int J Cardiol 2010; 142: 273-278.

10 Young RP, Hopkins R, Eaton TE. Pharmacological actions of statins: potential utility in COPD. Eur Respir Rev 2009; 18: 222-232.

DOI: 10.1183/09031936.00041711

From the authors:

We thank R.P. Young and co-workers for their comments on our recent article [1]. As we highlighted in our article, there are two recent reports indicating that single-nucleotide polymorphisms in the advanced glycosylation end product-specific receptor (AGER) gene, which encodes the receptor for advanced glycation end-products (RAGE), are associated with changes in measurements of airflow obstruction $[2,3]$. The findings reported by R.P. Young and co-workers in their correspondence add to these earlier studies and shed light on the genetic basis by which cigarette smoke exposure leads to chronic obstructive pulmonary disease (COPD) in some individuals, while "resistant smokers" maintain normal lung function.
Our finding that circulating levels of soluble RAGE (sRAGE) are lower in COPD subjects than healthy controls has since been reproduced in a study reported recently by MiNIATI et al. [4]. Within an individual, circulating levels of sRAGE may be determined by polymorphisms in the AGER gene, but are also susceptible to environmental factors, especially as plasma sRAGE levels are very low during acute exacerbations of COPD and rise during convalescence [1]. There is now a need for longitudinal studies to define the relationship between polymorphisms in the AGER gene and circulating levels of SRAGE in patients with COPD, and to assess the extent to which this predicts rate of decline in lung function over time.

\section{J.W. Upham *\#, D. J. Smith", and S.T. Yerkovich",}

*Dept of Respiratory Medicine, Princess Alexandra Hospital,

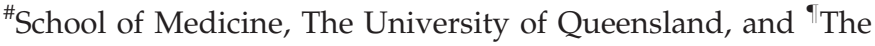
Prince Charles Hospital, Brisbane, Queensland, Australia.

Correspondence: S.T. Yerkovich, The University of Queensland, Level3, R Wing, Building 1, Princess Alexandra Hospital, Brisbane, QLD 4102, Australia. E-mail: Stephanie_Yerkovich@health.qld. gov.au

Statement of Interest: None declared.

\section{REFERENCES}

1 Smith DJ, Yerkovich ST, Towers MA, et al. Reduced soluble receptor for advanced glycation end-products in COPD. Eur Respir J 2011; 37: 516-522.

2 Hancock DB, Eijgelsheim M, Wilk JB, et al. Meta-analyses of genome-wide association studies identify multiple loci associated with pulmonary function. Nat Genet 2010; 42: 45-52.

3 Repapi E, Sayers I, Wain LV, et al. Genome-wide association study identifies five loci associated with lung function. Nat Genet 2010; 42: 36-44.

4 Miniati M, Monti S, Basta G, et al. Soluble receptor for advanced glycation end products in COPD: relationship with emphysema and chronic cor pulmonale: a case-control study. Respir Res 2011; 12: 37.

\title{
Can dog allergen alone, if combined with indoor pollution, be responsible for asthma in children?
}

\section{To the Editors:}

We read with interest the article by CARLSTEN et al. [1] showing the increasing risk of incident asthma in a high-risk birth cohort after early co-exposure to dog allergen (Can $\mathrm{f} 1$ ) and nitrogen dioxide $\left(\mathrm{NO}_{2}\right)$ or environmental tobacco smoke. The topic is highly relevant because most studies on the interaction between allergens and air pollution regard outdoor environments and very few articles have been published on the possible allergen-pollutant relationship in indoor places.
Nevertheless, we think that other limitations to the study should be considered in addition to those already acknowledged by the authors. In their study, they referred to the article of MCCONNELL et al. [2] that showed a significant association between "bronchitis symptoms" and particulate matter only in the subset of asthmatic children who owned dogs. However, MCCONNELL et al. [2] examined the relationship of both dog and cat ownership with air pollution, and reported that effects 